\title{
German and Nordic Perspectives on Company Law and Capital Markets Law
}

\author{
Ed. by Holger Fleischer, Jesper Lau Hansen and Wolf-Georg Ringe \\ [Deutsche und nordische Perspektiven zum Gesellschaftsrecht und Kapitalmarktrecht.]
}

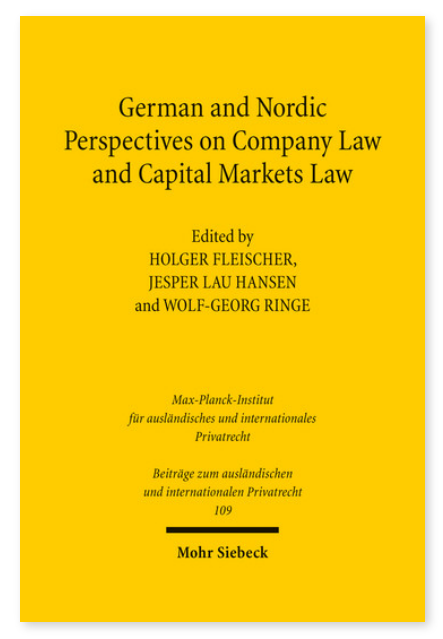

2015. XII, 275 Seiten. BtrIPR 109

ISBN 978-3-16-153956-5

DOI 10.1628/978-3-16-153956-5

eBook PDF 79,00€

ISBN 978-3-16-153907-7

Leinen $79,00 €$
Veröffentlicht auf Englisch.

Dieser Band geht auf ein Symposium am Hamburger Max-Planck-Institut für ausländisches und internationales Privatrecht in Hamburg zurück. Er bietet erstmals einen breiten Vergleich gesellschafts- und kapitalmarktrechtlicher Fragen in Deutschland und den nordischen Ländern. Erläutert werden die Besonderheiten des Gesellschaftsrechts in Skandinavien, das sich in einem Spannungsfeld aus Experimentierfreude und Innovation einerseits und Harmonisierung andererseits entwickelt. Dem werden die charakteristischen Merkmale und Eigenheiten des deutschen Gesellschaftsrechts gegenüber gestellt. Weitere Beiträge betreffen die neu geschaffene Unternehmergesellschaft in Deutschland und Dänemark sowie die Rolle der Anteilseigner und des Aufsichtsrats bzw. Verwaltungsrats in Publikumsgesellschaften. Außerdem finden sich eingehende Analysen der konzernrechtlichen Regelungen in Deutschland und den nordischen Staaten vor dem Hintergrund einer möglichen Harmonisierung in Europa. Abgerundet wird der Band durch Beiträge zum Kapitalmarkt- und Übernahmerechts. Erörtert werden insbesondere Fragen des Acting in Concert, der Beteiligungstransparenz und des Zusammenspiels zwischen Gesetzgeber und Takeover Panel in Schweden.

Inhaltsübersicht

Part I - Overview of Company Law and Types in Germany and the Nordic Countries

Holger Fleischer: A Guide to German Company Law for International Lawyers - Distinctive Features, Particularities, Idiosyncrasies - Jan Andersson: Company Law as a Product in Scandinavia versus EU - Experimentation and Innovation versus Harmonization

Part II - The Law of Private Limited Companies

Frauke Wedemann: Reforming the Law of Limited Liability Companies in Germany - Troels Michael Lilja: Entrepreneur Companies in Denmark and Germany - On the Danish IVS and the German UG (haftungsbeschränkt)

Part III - The Role of Shareholders and Boards in Public Companies

Jesper Lau Hansen: The Role of Shareholders in Public Companies in the Nordic Countries - Christian Kersting: The Role of Shareholder in Public Companies in Germany - Paul Krüger Andersen/Evelyne JB Sørensen: The Danish Supervisory Board - a German Model?

\section{Part IV - Groups of Companies}

Tobias Tröger: Corporate Groups - A German's European Perspective - Søren Friis Hansen: Introduction to Scandinavian Nordic Group Law

Part V - Capital Markets in Perspective

Dirk Verse: Acting in Concert in German Company and Takeover Law - Marrten Knuts: The Disclosure of Cash Settled Equity Derivatives - Will the Proposed Amendments Solve the Problems? - Göran Nyström/Erik Sjöman: The Regulation of Takeovers in Sweden - An Interplay Between the Rulemaker and the Takeover Panel

Holger Fleischer is Director at the Max Planck Institute for Comparative and International Private Law in Hamburg and Affiliate Professor at the Bucerius Law School, Hamburg.

Jesper Lau Hansen is Professor of Financial Markets Law at the University Copenhagen.

Wolf-Georg Ringe is Professor of International Commercial Law at Copenhagen Business School and also teaches at the University of Oxford.

Jetzt bestellen:

https://mohrsiebeck.com/buch/german-and-nordic-perspectives-on-company-law-and-capital-markets-law-9783161539565? no_cache=1

order@mohrsiebeck.com

Telefon: +49 (0)7071-923-17

Telefax: +49 (0)7071-51104 